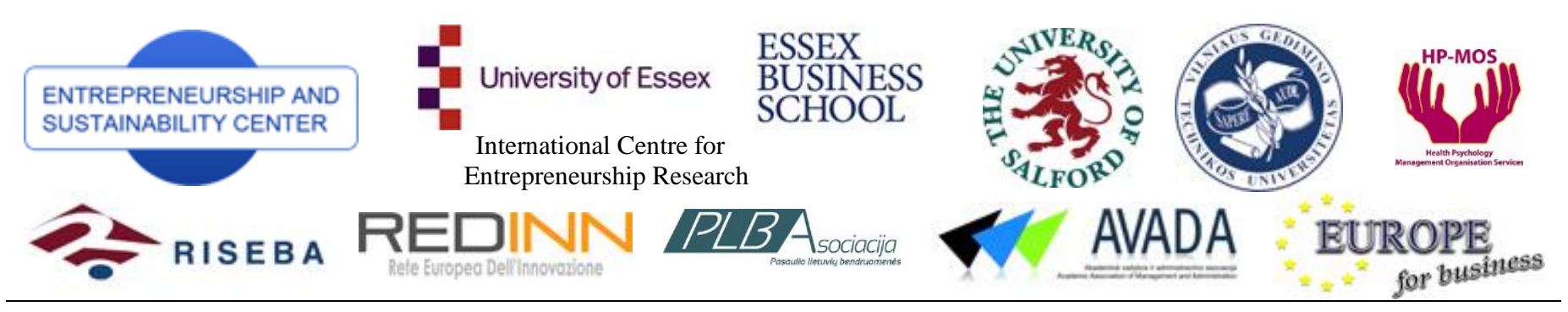

ENTREPRENEURSHIP AND SUSTAINABILITY ISSUES

ISSN 2345-0282 (online) http://jssidoi.org/jesi/aims-and-scope-of-research/

\title{
MODEL OF MOTIVATING LINKED-UP WITH EDUCATION
}

\author{
Lenka Tarábková \\ Faculty of Management Science and Informatics, Department of Management Theories \\ Univerzitná 8215/1, 01026 Žilina \\ E-mail: Lenka.Tarabkova@fri.uniza.sk
}

Received 15 July 2014; accepted 30 August 2014

\begin{abstract}
Investing in people and principally in their skills and knowledge is becoming the fundamental prerequisite for gaining sustainable and strategic competitiveness at the market. The article deals with the problematic of business education, which in much foreign literature is predominantly known as workplace learning. This problematic is being studied in the context of three constructs motivation, education and feedback. The value of this article is that it proposes the model of motivating of employees which is linked-up with educational process. The article is divided into two main parts, the first part deals with the literature review and the second one describes the proposed model.
\end{abstract}

Keywords: motivation, motivating, education, learning, model

Reference to this paper should be made as follows: Tarábková, L. 2014. Model of motivating linked-up with education, Entrepreneurship and Sustainability Issues 2(1): 12-18.

DOI: http://dx.doi.org/10.9770/jesi.2014.2.1(2)

JEL Classifications: M12

\section{Introduction}

Businesses face a permanent changing environment due to new challenges such as globalization, economic pressures, and the changing nature of work (Šabasevičienè, Grybaitė 2014; Tvaronavičienè 2014; Prause, Hunke 2014). To be successful, employees must learn to cope with such changes (Wang et al. 2011: 260; GarškaitèMilvydienè 2014; Litvaj, Poniščiaková 2014; Dzemyda, Raudeliūnienė 2014). Many authors highlight the importance of employees' knowledge and skills in the effort of managers to make the business competitive not only at local marketplace (Lengnick et al. 2003; Carneiro 2000; Figurska 2014; Išoraitė 2013; Laužikas, Mokšeckiene 2013). The paradigm of knowledge and its role in competitiveness enhancement is also dealt on national or supranational level (Sum, Jessop 2013). Moreover, the way the entire business learns can be instrumental in its innovation and profitability (Vaughan 2008; Išorate et al. 2014). If we want to support employees to enhance their ability to react on changes, the business has to create and foster appropriate environment regarding three crucial constructs, i.e. motivation, education and feedback which are closely described in the article.

\subsection{Motivation}

The importance of employee motivation to perform well in tasks is widely recognized (Chong, Roopnarain 2014: 229). There is an extensive literature on motivation. It has been defined as: the psychological process that gives 
behaviour purpose and direction (Kreitner 1995); an internal drive to satisfy an unsatisfied need (Higgins 1994); and all those inner-striving conditions described as wishes, desires, drives, etc. (Gibson et al. 1994). To put it simply, motivation is a force that causes a person to behave in a certain way.

Generally, there are two types of motivation which are important to distinguish, intrinsic and extrinsic. Intrinsic motivation is defined as the doing of an activity for its inherent satisfactions rather than for some separable consequence. When intrinsically motivated a person is moved to act for the fun or challenge entailed rather than because of external prods, pressures, or rewards. On the other hand, extrinsic motivation is a construct that pertains whenever an activity is done in order to attain some separable outcome (Ryan, Deci 2000: 56-60). When talking about motivation at the workplace, extrinsic motivation becomes intentional but still positive motivating of employees by their managers in order to perform according to set standards or even exceed them. It is necessary to point out that motivating (an intentional intervention into inner motives of an employee) is not stimulating (such an intentional intervention which does not try to start up inner motives, just to make an employee comply with given tasks).

\subsection{Education and workplace learning}

Not only businesses but also our society needs people with high level of knowledge, skills and abilities. Learning and development process is defined as the process of ensuring that the business has the knowledgeable, skilled and engaged employees it needs (Armstrong 2012: 274). There are several terms which are often interchanged in the meaning - education, training, and learning as can be seen from next definitions:

- Education also known as Training and Development, Human Resource Development, Corporate Training, and Work and Learning - can be defined as the means, processes, and activities in the workplace by which employees learn basic skills, high technology, and management practise that can be immediately applied to their jobs, duties, and roles in the business. Indeed, to compete and keep up with changes, businesses require effective ways to update their workforce's skills and knowledge (Wang et al. 2011: 261).

- Education is seen as education in school, also called schooling or vocational educational learning. It is more comprehensive and extended. Training, also called workplace learning, is more specific and bounded, is aimed at creating a competence development in specific practise (Cairns and Malloch 2010: 8-9).

- Learning should be distinguished from training. Learning is the process by which a person constructs new knowledge, skills and capabilities; whereas training is one of several responses a business can undertake to promote learning. Learning is what individuals do; training is what businesses do to individuals (Armstrong 2012: 274).

- Workplace learning has a broader project and potential to link development of the individual with development of the organisation or business, through an emphasis on sustained development and learning processes as well as learning outcomes (Vaughan 2008).

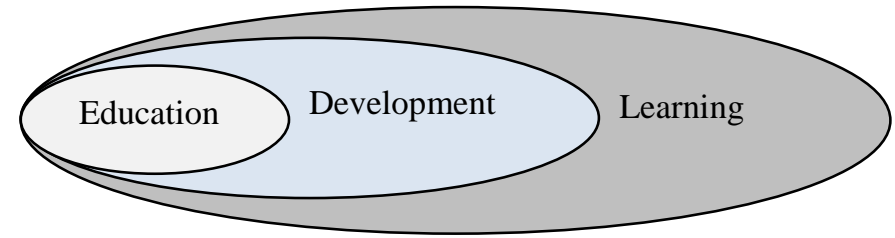

Fig.1. Relationship among education, development and learning

Source: author

In this article as is understood in many Slovak and Czech literatures, the business education is referred as a systematic process organized by the business aiming at acquiring new and developing current level of knowledge, skills and abilities in order to better perform at given tasks. The result of business education is a reduction of gap in job performance between what exists and what is needed. Development means acquiring new 
knowledge and attitudes which are required in terms of long-term development of individual's career and business goals. Learning as highest stage of education means mainly experience and practise, it cannot be designed in advance and is rather a matter of individual or personal change. This can be shown in Figure 1.

\subsection{Importance of feedback on learning}

There are many articles or books which operate with the word feedback. Every day we use it unconsciously without questioning the meaning or the purpose of it. Broadly speaking, feedback is understood as the return of information about the result of a process or an activity, an evaluative response ${ }^{1}$ to a person from an agent (teacher, partner, co-worker, supervisor, computer programme, etc.). Feedback has considerable importance in learning (Bosc-Mine 2014; Boero, Novarese 2012; Race 2001). If the person accepts and considers the received feedback, such information can be used to modify their characteristics and behaviour. Not only does feedback help learners understand the subject being studied, it helps them quickly master new knowledge. Furthermore, it gives then clear guidance on how to improve their learning ${ }^{2}$.

\section{Model of motivating linked-up with education of employees}

The basic prerequisite of this article is the fact that there is a strong linkage between motivating and educating of employees. In practise there can be two types of interaction between motivating and education. First, the education itself can be comprehended as the motivational tool when employees perceive opportunity to develop or deepen their skills and knowledge strongly motivationally. Second, to make the most of business education it is necessary to motivate employees, therefore, to elaborate a motivational programme for efficient education and knowledge transfer into practise.

As a result of this prerequisite, the model where motivating and education are interconnected is proposed (Figure 2). The mutual interconnection brings a synergic effect which could result in higher commitment of employees. If personal and professional development of employees is supported, easier, faster and above all for longer time period it will result in profounder identification with business goals and willingness to contribute to market success of the business.

Any concept for work with human potential of the business has to stem from the vision, mission, goals and business strategy as well as particular SBU's goals and strategies. An essential forming part of the concept is the philosophy and culture, which are closely linked with values and principles within the business. These are the premise for strategy and policy of human potential management and development. In general, the strategy of development of employees can be described as the strategy that expresses the capabilities, skills and knowledge which are required and how to develop these in order to achieve strategic market success. Based on this strategy, the business motivational programme can be drafted. Motivational programme (or incentive scheme) is an internal document which obtains a set of goals, criterions, tools, attitudes and procedures designed to encourage commitment of employees.

The first step in the model is an analysis of needs and motives, which based on motivational and performance evaluation interviews or questionnaire survey (or other methods common in the business) is investigating the state of the knowledge, abilities, interests and work attitude and motivational profile of an employee, i.e. what motives to highly perform at work and self-educate he or she has got. To obtain truly complex picture it is necessary to investigate job satisfaction (work environment, interpersonal relationships and communication, remuneration, performance evaluation, etc.). Comprehensive analysis of needs helps document actual deficiencies and problems. A thorough analysis of insufficient gap between required job performance and the real one is a starting point for business education planning.

\footnotetext{
${ }^{1}$ www.thefreedictionary.com

${ }^{2}$ University of Readining.
} 


\section{ViSSION, MisSION, GOALS AND BUSINESS STRATEGY}

\section{FHILOSOPHY AND CUlture V VALUES AND PRINCIPLES}

STRATEGY OF HUMAN POTENTIAL MANAGEMENT AND DEVELOPMENT

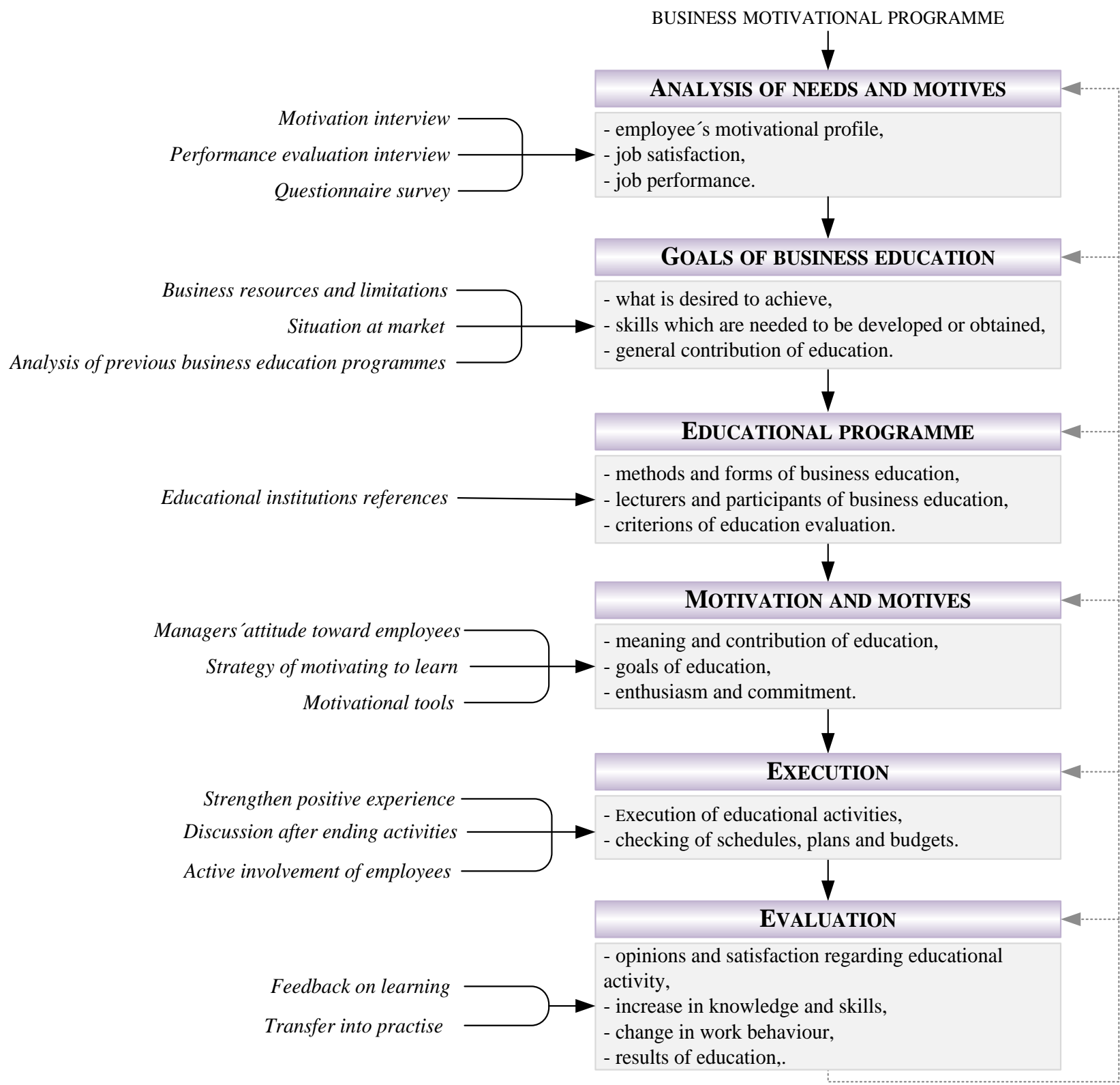

Process feedback

Fig.2. Model of motivating linked-up with education

Source: author

The second step is setting the goals of business education where it is necessary to identify and specify requirements regarding education, i. e. what is desired to achieve, which skills and knowledge are asked to be deepen or obtained. It is important to emphasis the general contribution of education in long-term point of view to all employees. Valuable source of information for this step is a scrutiny of previous educational programmes. 
In decision making it is important to take into account business resources and limitations (human, financial, physical, intangible, time), the situation at market (the education should reflect the latest or coming changes) as well as competitors's steps.

The subsequent step is elaboration of an educational programme which comprises decision making about methods, forms, schedules, lecturers and participants of educational activities. The key role of the programme is to define basic criterions against which effectiveness and outcomes of particular educational activities will be evaluated. The selection of educational institution carrying out the educational programme can be done on the basis of looking for references on educational institutions and what added value they can provide.

Motivation and motives step represents the crucial one regarding motivational-educational effort of every business since it creates the opportunity to emphasis the strategic meaning and contribution of the education and explicitly refer to job position (how education will influence their performance). The better the employees are informed about goals of education, the more they are involved and willing to transfer new knowledge into practise. Within this step, managers' attitude is crucial as well as their motivation to motivate subordinates. Based on motivation strategy and knowledge of employees' motivational profile, the proper motivational tools in the realm of communication (acknowledgement, praise and empathy), leading (asking for opinions, discussing, providing immediate feedback and empowerment) and employee evaluation (openness, emphasising of strengths) can be used in everyday practise.

The fifth step represents the execution of education itself. Among many available methods used in educational process, business should deploy on-the-job methods such as coaching and mentoring. In order to strengthen the experience, it is necessary to continuously positively engage employees into activities even after ending education, e.g. planning or modifying forms of next educational activities. Furthermore, participants should be allowed to meet and discuss what they have taught in form of discussions, chats, communities of practise, knowledge cafes $^{3}$ (Leask 2008).

The last step, evaluation as a systematic appraisal of the quality of teaching and learning in order to improve future education, provides feedback on the effectiveness of educational programme. Unfortunately, many companies are reluctant to measure or evaluate the effectiveness of education for various reasons (difficulties to set proper measures, lack of knowledge how to evaluate, etc.). Nevertheless, evaluating the process and seeing the real results of education in form of examples from practise can provide the proof of rightfulness of education (employees can experience so-called "click" effect of the purpose) ${ }^{4}$. Evaluation needs to cover four realms: reactions (mainly feelings, ideas, satisfaction with the content, methods, lecturers, etc.), learning (the amount of new knowledge and skills learnt), change in behaviour (which learnt knowledge was transferred into practise) and results (the impact of education on corporate performance measured on the base of key performance indicatiors). Generally, evaluation embodies a feedback on learning which squares the quality of future learning process of the employees.

Finally, the very last part of the model is process feedback which retrospectively tracks possible resources of mistakes or errors which could occurred somewhere along the whole process starting with evaluation step and ending with the definition of vision, mission, goals and business strategy. It checks whether the error was caused during execution of education, whether participants were motivated properly, whether correct educational goals were specified or whether defined needs of education and development were accurate.

\section{Conclusions}

So the world of work is becoming more complex and uncertain as old categories and rapid change make it harder to predict occupational futures and very specific skills needs. Everyone needs the capacity to adapt, change and innovate. Workplace learning becomes a tool through which businesses may gain competitive advantage

\footnotetext{
${ }^{3}$ A group of people having an open, creative conversation in an informal environment on a topic of mutual interest

${ }^{4}$ Click effect - when a person suddenly becomes aware of something
} 
(recruitment and retention of workers, development of innovative practices, and the production of new knowledge) (Vaughan 2008).

According to new statistics released by the CIPD the businesses are waking up to the changes in the world of work by aligning learning and developing initiatives to business strategy. Reflecting the increasing emphasis on evaluating business education, the survey revealed that the number of businesses measuring return on investment from development practices has increased from $26 \%$ to $48 \%$ (CIPD 2014).

Undoubtedly, there is a positive strong relationship between business education and the performance of the business. Therefore futher research in area of education should focus on ascertaining factors which constitute successful learning and knowledge transfer into practise in terms of linking results of education with performance of the business.

\section{References}

Armstrong, M. 2012. Armstrong's Handbook of Human Resource Management Practice. $12^{\text {th }}$ edition. Kogan Page.

Bosc-Mine, Ch. 2014. Properties and functions of feedback in learning, Annee Psychologique 114(2): 315-353.

Boero, R.; Novarese, M. 2012. Feedback and Learning, in Seel, N.M. (Ed.). Encyclopedia of the Sciences of Learning, $1282-1285$. DOI: $\underline{10.1007 / 978-1-4419-1428-6 \_939}$

Cairns, L.; Malloch, M. 2011. Theories of Work, Place and Learning: New Directions, in Malloch, M.; Cairns, L.; Evans, K.; O'Connor, B. (Eds.). The international handbook of workplace learning, 3-16. London: Sage.

Carneiro, A. 2000. How does knowledge management influence innovation and competitiveness? Journal of Knowledge Management 4(2): 87-98.

Chong, L. M.; Roopnarain, K. 2014. The effects of nonfinancial and financial measures on employee motivation to participate in target setting, The British Accounting Review (in Press).

CIPD: Learning and development becomes more business focused. 2014. Available on the Internet: 〈http://www.cipd.co.uk/pressoffice/press-releases/learning-development-business-focused-cipd-300414.aspx) >.

Dzemyda, I.; Raudeliūnienè, J. 2014. Sustainable youth entrepreneurship in conditions of global economy toward energy security, Entrepreneurship and Sustainability Issues 1(4): 247-256. DOI: http://dx.doi.org/10.9770/jesi.2014.1.4(7)

Garškaitè-Milvydienė, K. 2014. Anti-crisis management of enterprises and possibilities of overcoming their critical condition, Journal of Entrepreneurship and Sustainability Issues 1(4): 187-203. DOI: http://dx.doi.org/10.9770/jesi.2014.1.4(1)

Higgins, J. M.: 1994. The management challenge. $2^{\text {nd }}$ edition. New York: Macmillan.

Išoraitè, M. 2013. Motivation tools though lenses of prospective employees, Entrepreneurship and Sustainability Issues 1(2): 116-123. DOI: http://dx.doi.org/10.9770/jesi.2013.1.2(6)

Išoratè, M.; Steiblienė, L.; Mečèjienè, G. 2014. If obtained professional competences are suitable for sustainable entrepreneurship: case of Vilnius University of Applied Sciences, Entrepreneurship and Sustainability Issues 1(4): 239-246. DOI: http://dx.doi.org/10.9770/jesi.2014.1.4(6)

Figurska, I. 2014. Sustainable entrepreneurship: localization, acquiring and use of knowledge sources in competitive organization, Entrepreneurship and Sustainability Issues 1(4): 210-222. DOI: http://dx.doi.org/10.9770/jesi.2014.1.4(3)

Gibson, J. L.; Ivancevich, J. M.; Donnelly, J. H. 1994. Organizations: Behavior, structure, processes. $8^{\text {th }}$ edition. Homewood, IL: Irwin.

Kreitner, R. 1995. Management. $6^{\text {th }}$ edition. Boston: Houghton Mifflin.

Laužikas, M.; Mokšeckienè. 2013. The role of creativity in sustainable business, Entrepreneurship and Sustainability Issues 1(1): 10-22. DOI: http://dx.doi.org/10.9770/jesi.2013.1(2) 
Leask, M.; Caren, L.; Milner, T.; Norton, M.; Rathod, D. 2008. Knowledge management tools and techniques: helping you access the right knowledge at the right time. Improvement and development agency for local government. Available on the Internet: <http://www.idea.gov.uk/idk/aio/8595069>.

Lengnick, H.; Lengnick-Halll, C. 2003. Human Resource Management in the Knowledge Economy: New Challenges, New Roles, New Capabilities. Berrett-Koehler Publishers.

Litvaj, I.; Poniščiaková, O. 2014. Entrepreneurship and quality management, Entrepreneurship and Sustainability Issues 1(4): $204-209$. DOI: http://dx.doi.org/10.9770/jesi.2014.1.4(2)

Prause, G.; Hunke, K. 2014. Sustainable entrepreneurship along green corridor, Entrepreneurship and Sustainability Issues 1(3): 124133. DOI: http://dx.doi.org/10.9770/jesi.2014.1.3(1)

Race, P.: 2001. Using feedback to help students learn. The Higher Education Academy.

Ryan, R. M.; Deci, E. 2000. Intrinsic and Extrinsic Motivations: Classic Definitions and New Directions, Contemporary Educational Psychology 25: 54-67. DOI: 10.1006/ceps.1999.1020

Šabasevičienė, V.; Grybaite, V. 2014.Main foreign direct investment factors as precondition of sustainable entrepreneurship: evidence from Lithuania, Central and Eastern Europe, Entrepreneurship and Sustainability Issues 1(4): 230-238. DOI: http://dx.doi.org/10.9770/jesi.2014.1.4(5)

Sum, N.; Jessop, B. 2013. Competitiveness, the knowledge-based economy and higher education, Journal of the Knowledge Economy 4(1): 24-44.

Tvaronavičienė, M. 2014. If industrial sector development is sustainable: Lithuania compared to the EU, Entrepreneurship and Sustainability Issues 1(3):134-142. DOI: http://dx.doi.org/10.9770/jesi.2014.1.3(2)

Vaughan, K. 2008. Workplace learning: a literature review. Competenz. Available on the Internet: <https://akoaotearoa.ac.nz/download/ng/file/group-189/n1575-workplace-learning-a-literature-review.pdf>.

Wang, M.; Vogel, D.; Ran, W. 2011. Creating a performance-oriented e-learning environment: A design science approach, Elsevier 48(7): 260-269. DOI:10.1016/j.im.2011.06.003

University of Readining: Why is learning important? 2014. Available on the Internet: 〈http://www.reading.ac.uk/internal/engageinfeedback/Whyisfeedbackimportant/efb-WhyIsFeedbackImportant.aspx>. [Accessed: 5 May 2014]

Lenka TARÁBKOVÁ is a doctoral student at Faculty of Management Science and Informatics, Department of Management theories at the University of Žilina in Žilina, Slovakia. In dissertation research she deals with the topic of Corporate Performance Management, in particular how human resources education and development influences performance of the business.

\begin{tabular}{|l|l}
\hline$(\boldsymbol{c c}) \mathbf{E Y}$ \\
\hline
\end{tabular} This work is licensed under a Creative Commons Attribution 3.0 License. 